\title{
SZÁJSEBÉSZETI CÉLRA TERVEZETT FOGKÖZI CÉLZÓ TERVEZÉSI FOLYAMATA ÉS ANNAK NEHÉZSÉGEI
}

\section{THE DESIGN PROCESS OF INTERDENTAL TARGETING DESIGNED FOR ORAL SURGERY AND ITS DIFFICULTIES}

\author{
Csorba Béla István ${ }^{1^{*}}$, Dr. Urbán Gábor ${ }^{2}$ \\ 1 Innovatív Járművek és Anyagok Tanszék, GAMF Műszaki és Informatikai Kar, Neumann János Egyetem, \\ Magyarország \\ 2 Szájsebész, szaktanácsadó \\ https://doi.org/10.47833/2021.1.ENG.004
}

\section{Kulcsszavak: \\ Implantátum \\ Fog \\ Tervezés \\ fúró \\ szájsebészet}

\section{Keywords:}

Implant

Dental

Design

Drill

Oral Surgery

\section{Cikktörténet:}

Beérkezett 2021. március 4. Átdolgozva 2021. március 20. Elfogadva 2021. április 5.

\section{Összefoglalás}

Olyan mütéti fúrósablon tervezése volt a cél, ami sokrétüen állítható és több páciensnél alkalmazható. A tervezés során figyelembe kellett venni a költséghatékonyságot, a könnyü, gyors előállítást, a használhatóságot és az orvosi szempontból az alkalmazhatóságot.

A készülékkel szemben támasztott követelmények között az egyik legfontosabb a biológiai megfelelöség volt (anyagválasztás), emellett a kialakítás formája is lényeges volt, mert a készülék nem okozhat sérülést.

A tervezés folyamatában észlelt hibák, illetve nehéz gyárthatóság, vagy nem kellő megbízhatóság segítettek abban, hogy ráleljünk a megfelelö irányra. Ha kellett koncepciót váltottunk, ha kellett csak módosítottunk. Ennek folyományaként született meg a végleges változat, ami még a gyártás során további finomhangolást igényelhet.

\section{Abstract}

The aim of this research was to design an adjustable drill bushing device, which is applicable to more than one patient. In addition to cost-effectiveness, easy and fast production, the design had to be also easy for doctors to use.

Among the requirements for the device, the most important was biological compliance (choice of material), on the other hand, of course the shape of the design must not cause injury in the mouth.

During the designing the detected errors, difficult manufacturing or insufficient reliability can helps to create the final design. Thus, if we had to change a concept, we had to just modify it. As a result, the final version was born, which may require further fine-tuning during the manufacturing.

\footnotetext{
* Csorba Béla István. Tel.: +36 203714164

E-mail cím: csorba.bela@gamf.uni-neumann.hu
} 


\section{Bevezetés}

A szájsebészetben gyakran alkalmaznak olyan készülékeket, amelyek a fogpótlást elösegítő implantátum pontos behelyezését szolgálják. Manapság rengeteg eszköz van ezen cél megvalósítására, viszont az egyik legnagyobb hátránya az, hogy ezen eszközök csak egy beteg esetében használhatók. Ily módon minden egyes beteg fogpótlásához egyedi készüléket kell készíteni, amely nagyban megdrágítja a fogpótlás költségét. Ezen felül a fogpótláshoz szükséges implantátumok helyzetének pontos beállítása is bonyodalmat okoz.

Ezen cikk tartalma egy lehetséges megoldást ad ezen problémákra. A megtervezett készülék - amelynek tervezési folyamata e cikkben bemutatásra kerül - a fogpótláskor felmerülö minden lehetséges problémára megoldást kínál. Emellett a készülék használatával csökkenthetők a fogpótlás költségei, és ami az egyik legnagyobb előnye, hogy a készülék több beteg esetében is használható, mondhatni univerzális.

A készülék tervezése során a szájsebészet gyakorlati tapasztalataira támaszkodtunk.

\section{Koncepció}

A koncepció az volt, hogy olyan fogközi célzó készüléket tervezzünk, ami két fog között kialakult, egy, vagy több foghiány pótlásához többször is felhasználható sterilizálás után. A foghiányok területére vagy párhuzamosan kell két furatot készíteni (két foghiány esetén), vagy az implantátumokra tervezett szögtört fejeknek kell párhuzamosaknak lenni. Ha $10^{\circ}$ feletti a szögeltérés az implantátumfejek között, akkor a fogtechnikusnak nehéz a koronákat úgy kialakítani, hogy a fogorvos a szájba behelyezhesse a fogművet.

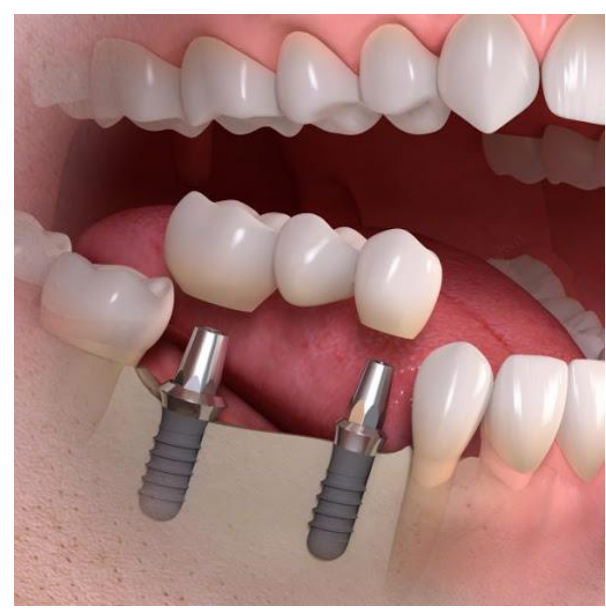

1. ábra Párhuzamos

implantátum elhelyezkedés

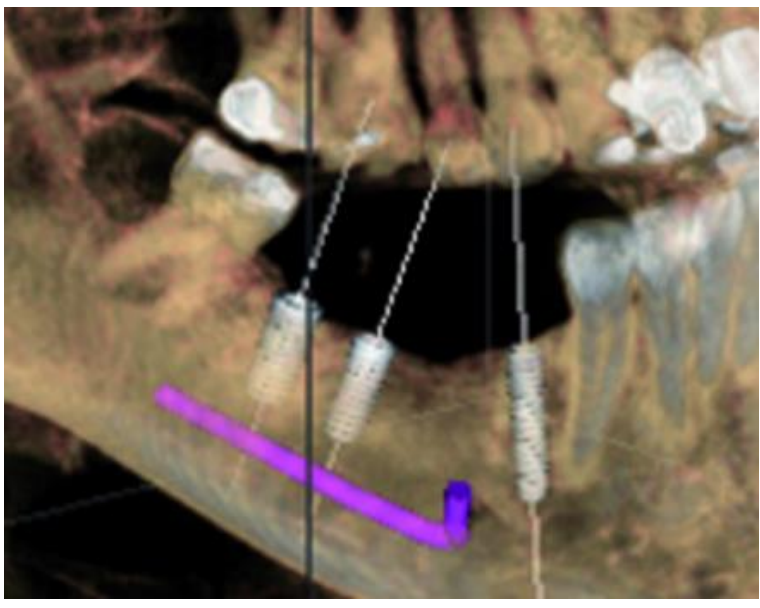

2. ábra Párhuzamosan és szögben eltérő helyzetben álló implantátum

Az 1. ábrán [1] párhuzamosan behelyezett implantátumok láthatók, amelyekre $10^{\circ}$-os fejek vannak rácsavarozva, majd erre kerülnek a fogkoronák.

A 2. ábrán [2] látható, hogy csak két implantátum párhuzamos egymással, a harmadik szögben áll ezekhez képest. Itt szükséges alkalmazni a szögtört fejet, vagy olyan fej használatát, amelyik kúpos, és nagyobb a kúp szöge, mint a tengelyeltérés az implantátumok között. Ezeket úgynevezett multi-unit fejeknek hívják. A lila színnel jelölt rész az állcsontban futó ideget szimbolizálja. Látható, hogy az implantátum nem éri el. Ha elérné, akkor az ideg sérül, vagyis érzés-, vagy mozgászavar lép fel az adott területen. Ez lehet átmeneti és végleges is. 


\section{Követelmények a célzóval szemben}

A fogközi célzó tervezése során a következő szempontokat kellett figyelembe venni.

\subsection{Implantátum nagyság, csontköpeny méret}

A behelyezendő implantátumok átmérője (3. ábra) [3] és hossza is változó, az implantátum átméröhöz egy $3 \mathrm{~mm}$-el nagyobb csontköpeny szükséges az implantátum megmaradása érdekében (4. ábra) [4]. Ha ez a méret kisebb, akkor a két implantátum közötti csontterület nem kap elég vérellátást, ezért leépül. Ez abban jelenik meg, hogy a kész fogmü alatt egyre nagyobb rés keletkezik, ahogy a csont leépülés folyamata zajlik, mivel a csont kisebbedésével a felette lévő íny is mélyebbre kerül. Elöbb-utóbb az implantátum is kilátszik az íny alól. Ez 2-3 év alatt az implantátum elvesztéséhez vezet.

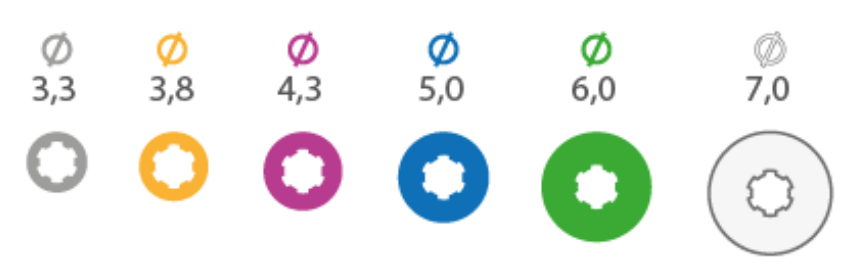

3. ábra Implantátum méretek

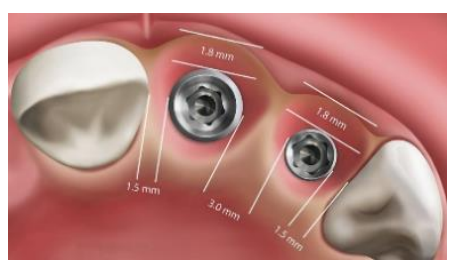

4. ábra Szükséges csontköpeny méretek

\subsection{Fogkorona méretek, implantátumra csavarható fejek}

Az egyes implantátumok tetejére (az ún. Abutmen-re, vagy fejekre) különböző átmérőjü fogkoronák készülnek, ráadásul ezek a koronaméretek függetlenek az implantátum átmérőjétöl. Keskeny implantátumra is kerülhet széles korona és fordítva.

Az implantátumba csavarható fejek (5. ábra) többféle szögben készülnek, vannak $0^{\circ}, 15^{\circ}, 17^{\circ}$, $20^{\circ}, 30^{\circ}$ kialakításúak. A fogtechnikus szempontjából a pótlás elkészítéséhez a fejek párhuzamossága a legfontosabb, általában $10-20^{\circ}$ eltérés is lehetséges attól függően, hogy milyen típusú fejröl van szó. [5]

Ez azt jelenti, hogy a párhuzamosan betervezett fejekhez képest az implantátumok szöge a párhuzamostól eltérhet, de csak az adott fej szögértékének megfelelően. Ennek megfelelően egy röntgenképen látszólag össze-vissza álló implantátumok megfelelö fejekkel tökéletes párhuzamosságot hozhatnak létre.

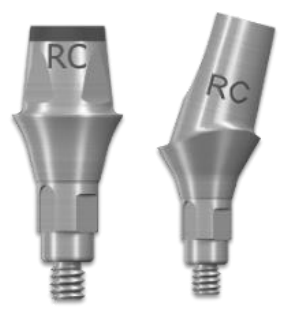

\section{5. ábra Fejkialakitások}

\subsection{Sebészi könyökfúró elhelyezése}

A sebészi könyökfúrónak (6.b ábra) [6] el kell férnie a célzó felett, vagyis a célzó 6-8 mm-nél nem lehet magasabb a szájnyitási korlátozottság miatt. Ennél nagyobb érték esetén a célzó a fúróval együtt nem férne be a beteg szájába, sőt a hátsó fogak pótlását gyakorlatilag nem lehetne megvalósítani (6.a és 6.c ábra). [7]; [8] 


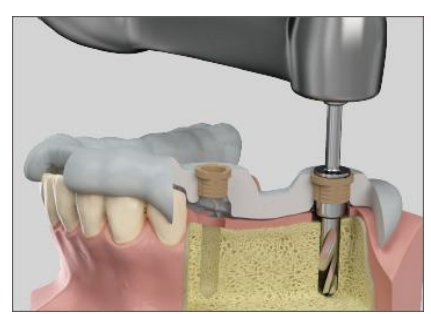

6.a ábra Könyökfúró fúrás közben hátsó fog esetén

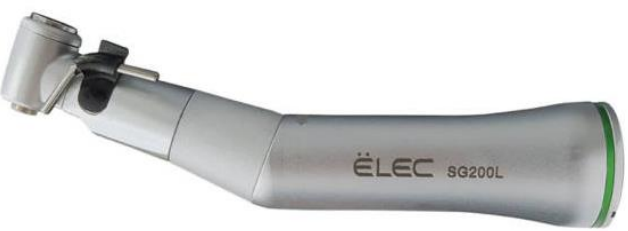

6.b ábra Könyökfúró

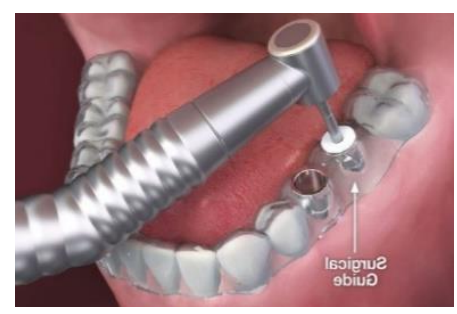

6.c ábra Implantátum helyének fúrása hátsó fogak esetén

\subsection{Készülék mérete, kialakítása, beállíthatósága, átláthatósága}

Az egész tervezett készüléknek elég kicsinek kell ahhoz lenni, hogy elférjen a beteg szájában, nem nyelheti le és éles szélek sem lehetnek rajta, amik nem kívánatos sérüléseket okozhatnak. Magának a készüléknek olyan kialakításúnak kell lennie, hogy az orvos számára egyértelmü legyen a készülék müködési elve, könnyen ellenörizhetö legyen a beállítások mértéke (véghelyzetben ütközik, kisebb jelölések az egyes darabokon, stb.).

\section{Fúróvezető sablonok típusai}

Manapság a fogászatban többféle célzó típus létezik. Ezek közül a legfontosabbak a 7-es számmal jelölt ábrákon láthatóak.

A 7.a ábrán [9] egy fogtechnikus által, kézzel készített nagyon egyszerű műanyag célzó látható, amely nem igazi célzó, de segítenek az orvosnak a tájékozódásban, ami teljes foghiány esetén nagyon fontos, mivel nincs viszonyítási pont.

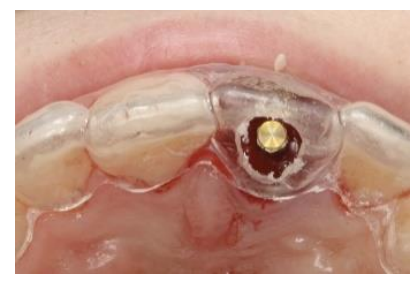

7.a ábra Müanyag célzó

Az 7.b - 7.f ábrákon digitális CT alapján megtervezett, 3D nyomtatóval legyártott mütéti sablonok láthatók, illetve azok sokszínüsége. [10] [11] [12] [13] [14]

Mindegyikre jellemző, hogy egy titán perselyt tartalmaz, amibe kisebb átmérőjű titán csöveket is be lehet csúsztatni (ún. szükítőket), és ezen keresztül lehet felfúrni megfelelő méretüre az implantátum helyét, szükítő nélkül pedig be lehet helyezni sablonon keresztül az implantátumot is. Ezek a sablonok nagyon precízek, de előálításuk komoly szakértelmet és időt igényel, emiatt drágák. Emellett fúráskor a hütést is akadályozzák, mert eltakarják a fúrás helyét, emiatt csak a szakaszosan lehet fúrni.

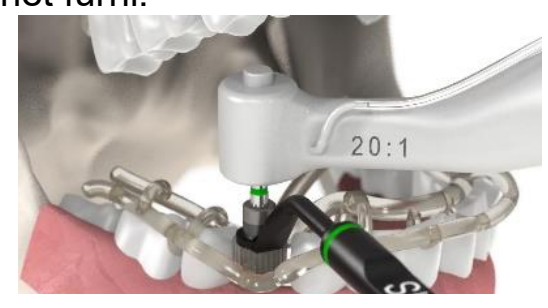

7.b ábra 3D nyomtatott sablon 1.

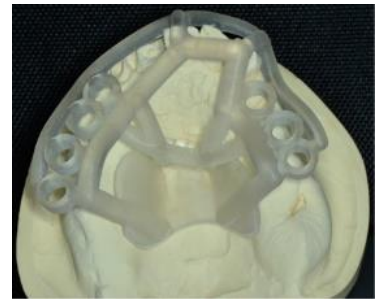

7.c ábra 3D nyomtatott sablon 2. 


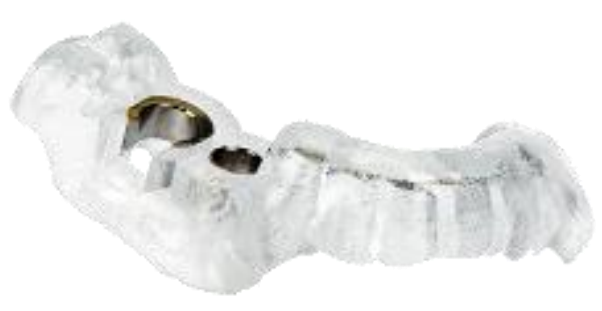

7.d ábra 3D nyomtatott sablon 3.

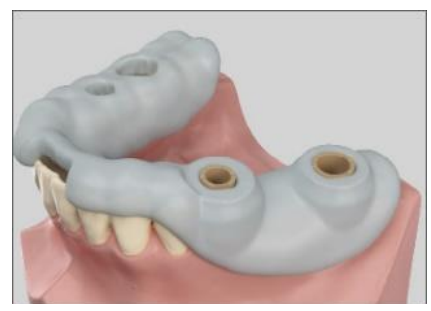

7.e ábra 3D nyomtatott sablon 4.

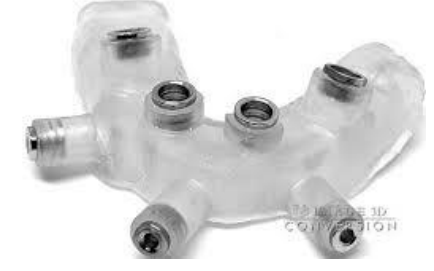

7.f ábra 3D nyomtatott sablon 5 .

Az 7.g ábrán [15] egy speciális fémeszköz látható, ami újra használható sterilizálás után és az elsőnek megfúrt lyukhoz képest segíti a következő furat helyének-irányának elkészítését. A pontos helyet a fémeszközön látható számérték mutatja.

A 7.h ábrasorozat [16] egy speciális mütéti sablont mutat be, ahol a fúróra van szerelve két csap, ami a sablonon kialakított két csőbe csúszik bele, így a furat helye teljesen szabad, ami a vízhütés miatt fontos. Mivel ez is ugyanazzal a digitális technikával készül, az ára ennek megfelelően szintén magas.

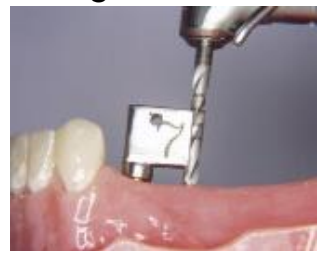

7.g ábra Fémeszköz
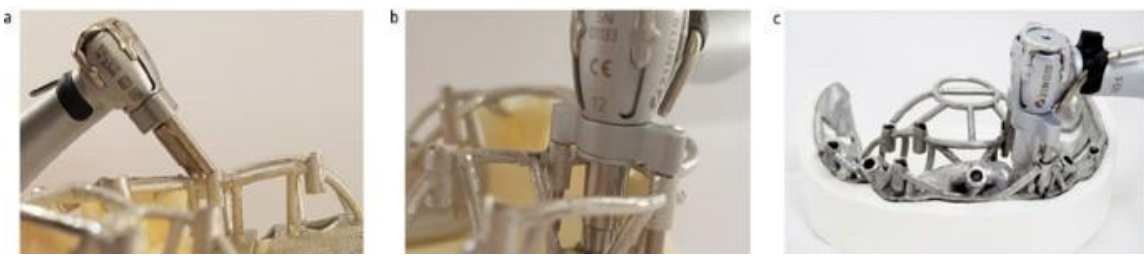

7.h ábra Speciális mütéti sablon

Az eddig bemutatott megoldások és információk birtokában a tervezés célja egy olyan fogközi célzó készülék tervezése volt, amely sterilizálás után több betegnél is, emellett többet tud, mint a 7.h ábrán bemutatott célzó. Véleményünk szerint költséghatékony lenne ennek a célzónak a beszerzése egy fogászati centrum számára és egy váratlan helyzetben is azonnal használható.

Érdekességképp egy furattal rendelkező célzó ára kb. $60.000 \mathrm{Ft}$ és a furatszámtól függően kb. 110000.-Ft-ig terjed az egy állcsonton használható mütéti sablon ára.

\section{Fúrási protokoll}

Az implantátumok helyének pontos elkészítéséhez szükségesek bizonyos szabályok, előírások betartása, amelyeknek meg kell felelni, hogy a fogpótlás sikeres legyen. Ezen szabályokra a 8. ábra [17] ad magyarázatot.

Az ábrán a fogak sorrendje, föbb méretei (a fogakba írt számértékek), a fogtengelyek egymástól mért távolsága (vastaggal szedett számok) és a fogszélektől mért következő fog tengelytávolsága (kis mérettel írt számok) olvasható le. Ezek csak irányelvek, mindig az adott betegre kell adaptálni ezeket az értékeket. A távolságértékek mm-ben vannak megadva.

Mütét közben ezek segítenek abban, hogy a lehetö legpontosabb helyre kerüljön az implantátum. Ez elméletileg a fog koronájának tengelyével párhuzamos implantátumot jelent, ami pontosan a korona tengelyében, vagy az alatt helyezkedik el (az implantátum középen támasztja alá a koronát). Ezen értékeket be kell tudni állítani a készüléken is. 


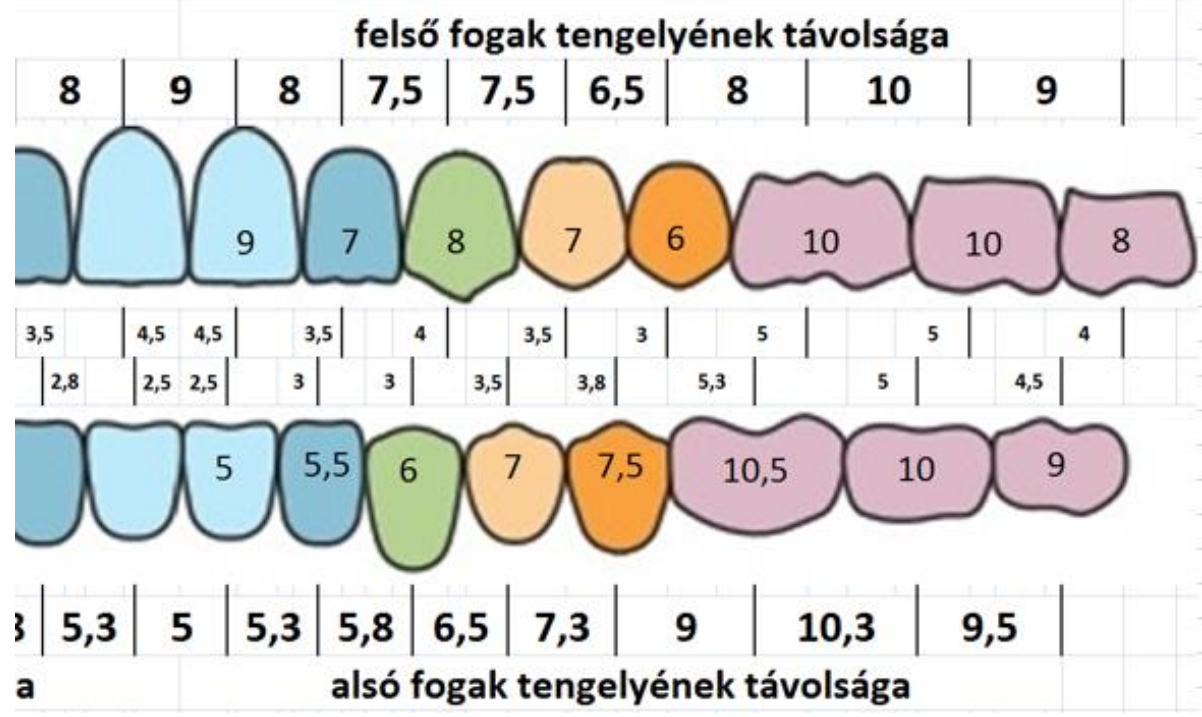

\section{8. ábra Távolság értékek $m m$-ben}

A 9. a ábrán [18] lévő röntgenképen úgy látszik, mintha a fogak egy szintben lennének, de a valóságban ez nem így van. Van olyan fog, amelyik alacsonyabban vagy magasabban van egy másik foghoz képest. Ez a szintkülönbség szintén gondot okoz, ennek kiküszöbölése is feladat, amely feladat megoldását is tudnia kell a készüléknek.

Emellett arra is kell figyelni, hogy a tengelyek ritkán párhuzamosak, mivel a fogak térgörbe mentén illeszkednek, melyet szemböl és oldalról is alátámasztanak, ezek látszódnak a 9.b és 9.c ábrán. [19] [20] Ezt a térgörbét, ívet a szájsebészetben Spee-görbéknek nevezik. Ezen ívek miatt a fogak tengelye a rágósíkhoz képest szöget zár be. Ezért legtöbbször nem függölegesen, hanem ferdén fúrunk a csontba.

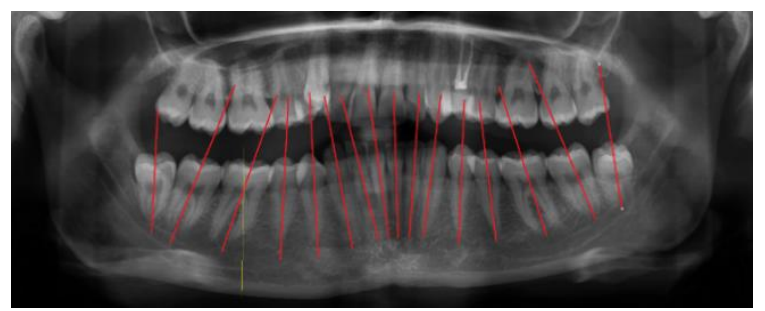

9.a ábra Röntgenkép

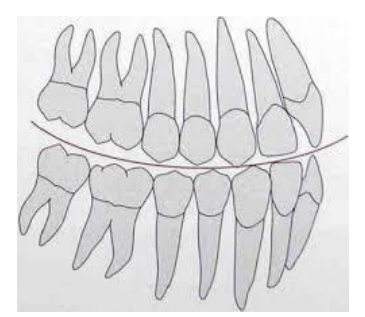

9.b ábra Spee görbe oldalról

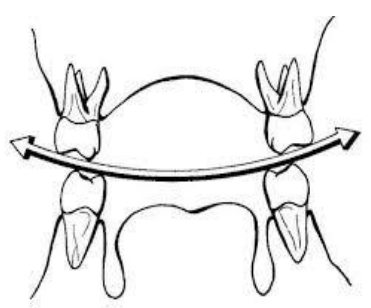

9.c ábra Spee görbe szemböl nézve 


\section{Tervezési sajátosság: visszafelé történő tervezés}

A szájsebészetben egy speciálisnak mondható tervezési módot alkalmaznak, amely az implantátum pontos helyének meghatározására szolgál. [21] Ennek magyarázatához a 10. számmal jelölt képsorozat szolgál.

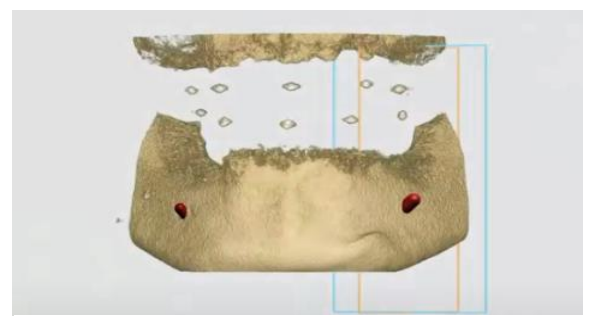

10.a ábra 3D CT csontkínálatról

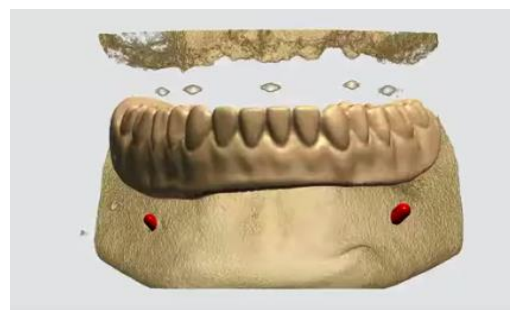

10.b ábra 3D CT kép csontkínálatról és a rajta elhelyezett fogazatról

Ahhoz, hogy jól funkcionáló és esztétikus fogakat lehessen készíteni, először a pótlandó fogakat meg kell tervezni (fogméret, fogalak, elhelyezkedés). A betegröl készített 3D-s CT felvételek alapján lehet felmérni azt a csontkínálatot, ami az adott betegnél rendelkezésre áll (10. a és 10. b ábra). [22] [23]

Ha a 3D CT felvételt CAD programban kiegészítjük a megtervezett fogak digitális képével, akkor a foghoz képest és a csontkínálatnak megfelelően a jó helyre tudjuk betervezni az implantátumokat (a fog tengelyében fog elhelyezkedni az implantátum, nem lesz túl mélyen, vagy magasan, nem sérti az ideget) (10.c ábra). [24]

Ha kész a digitális terv, akkor arról a speciális fogászati CAD program legenerálja a fúróvezető perselyeknek a helyét, dőlését, magasságát (10.d ábra). [25] [26]

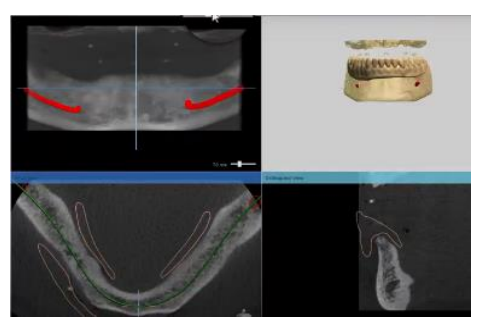

10.c ábra $3 D C T$ ás $C A D$ program kombinálása

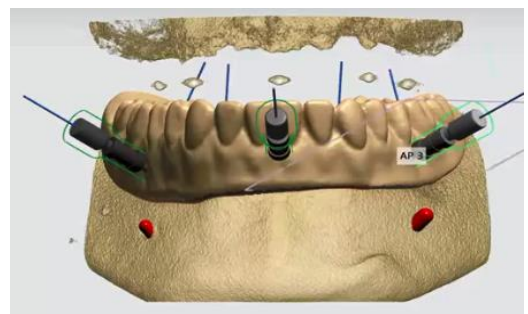

10.e ábra Hüvelyeket tartó sablon

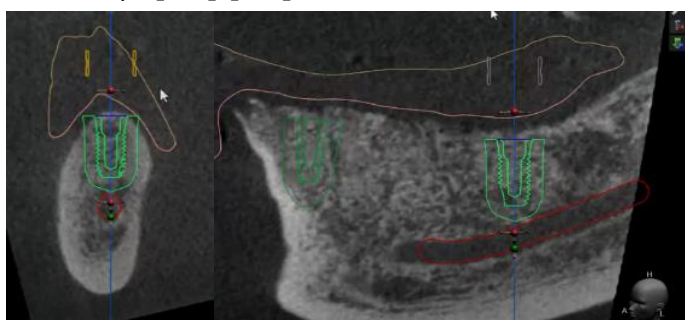

10.d ábra CAD program által generált persely hely

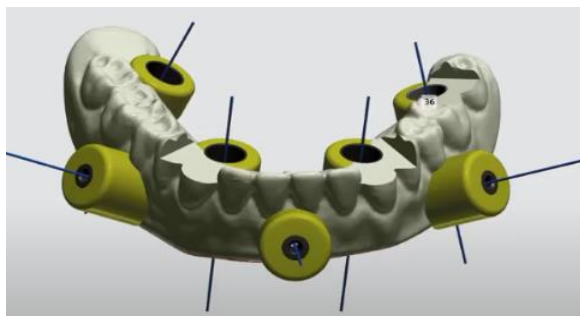

10.f ábra Rögzítő csavarok

A hüvelyek köré szintén a program tervezi meg automatikusan azt a sablont, ami tartja a hüvelyeket, illetve valamilyen módon vagy az ínyre, vagy a fogakra felfekszik (10.e ábra). [27] Ezáltal biztosítja, hogy az implantátum abban a pozícióban lesz a beteg szájába behelyezve, ahogy azt megterveztük, másképp a furatok sem kerülnek a helyükre. Ezt a pozícionálást és az elmozdulás megakadályozását segítik elő a rögzítő csavarok, ez látható a 10.f ábrán. [28] 


\section{A készülék kialakításának lépései}

A készülék megtervezéséhez és kialakításához a gépészetben alkalmazott $C A D$ szoftverek bármelyike alkalmas. [29] Esetünkben az Autodesk Inventor Professional szoftver volt számunkra legalkalmasabb. A szoftver könnyen kezelhetö, és a tervezés során ha módosításra került sor, akkor gyorsan meg lehetett oldani a program segítségével a változtatásokat.

\subsection{Első konstrukciós változat (11. ábra) [30]}

Az első konstrukciós változatban két implantátum helyét lehet elkészíteni. A tervezés során az elöbbiekben ismertetett követelményeket próbáltuk figyelembe venni. A szerkezet súlya minimális, a hosszú rúd (2) problémát okozhat a szájba történő behelyezéskor, viszont a készülék megtartásához szükséges a hosszabb kialakítás. A választott anyag minden konstrukciós változat esetében a titán, mivel ez az anyag nem káros a szervezetre.

Ennél a tervnél kiderült, hogy a sebészi könyökfúrónak (1) nincs elég helye nagyobb szögben való mozgatásához, vagyis nekiütközhet az egyes darabokhoz. A 3-as számmal jelölt darab kialakítása merevségi problémákat is felvet, mert a keskeny hosszú rúdrész letörhet a darabról, ha nagyobb igénybevétel éri a darabot. A 4-es számmal jelölt darab kialakítása gyártási problémát vetít elöre, ugyanis a darab méretéböl és kialakításából kiindulva hagyományos megmunkáló központokon a legyártás nehézkes, emellett megfelelő szerszám sincs ehhez a múvelethez, amely elkészítése komoly költségeket vonhat maga után, drágítva ezáltal a készülék árát.

Müködés szempontjából a készüléknél a függöleges irányú ( $z$ tengely), illetve a rúd tengelyére meröleges irányú ( $\mathrm{y}$ tengely) mozgás nem lehetséges. A beállíthatóság és átláthatóság biztosítottnak mondható. Az implantátumok megfelelő mérete, illetve a csontköpeny minimálisan szükséges mérete a két implantátum között megoldottnak mondható, amely az 5-ös számmal jelzett darabok egymás mellé helyezésével lemérhető. Ezen darabokban található egy-egy süllyesztett furat, amellyel meghatározható a maximálisan fúrható furat mélysége, mely által az idegek sérülése kiküszöbölhető. A darabok rögzítése egy adott pozícióban belsőkulcsnyílású csavarokkal történik (6).

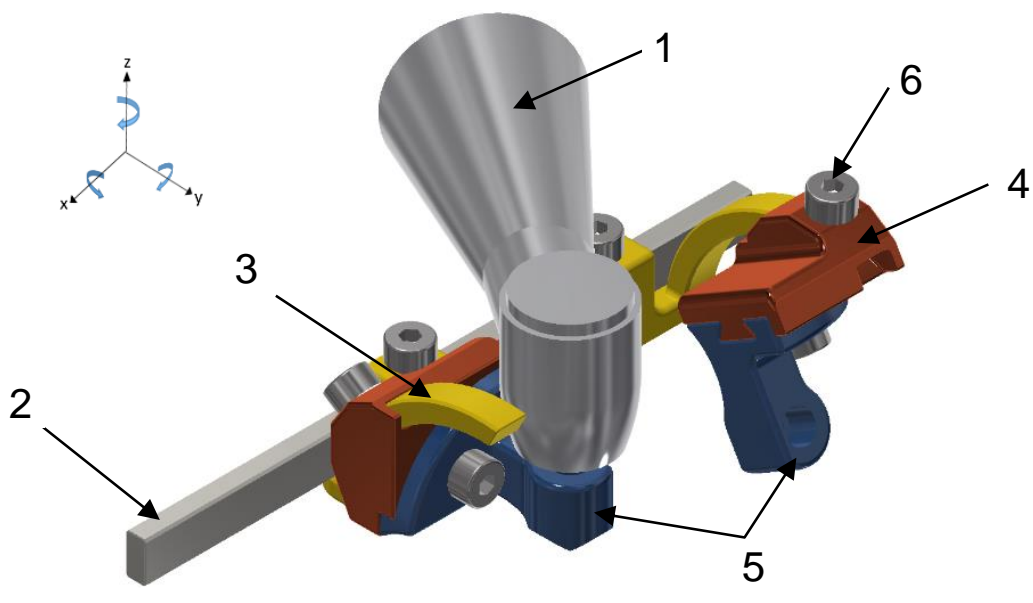

11. ábra Első konstrukció

\subsection{Második konstrukciós változat (12. ábra) [31]}

Ez a konstrukció nagyon hasonló, szinte ugyanaz, mint az előző, viszont a 4-es számmal jelölt darab kialakításán módosítottunk. A módosítás után a fúró már nem ütközik semminek, van már elég hely a fúró nagyobb szögben való mozgatásához. A függőleges irányú (z tengely), illetve a rúdra merőleges irányú ( $\mathrm{y}$ tengely) mozgás továbbra sem lehetséges, tehát az elvárt funkciókat nem teljesíti a készülék. Az egyes darabok rögzítése belsőkulcsnyílású csavar helyett már hernyócsavarral történik (6). A készülék súlya hasonlóan az előzőhöz $\sim 14-15 \mathrm{~g}$. 


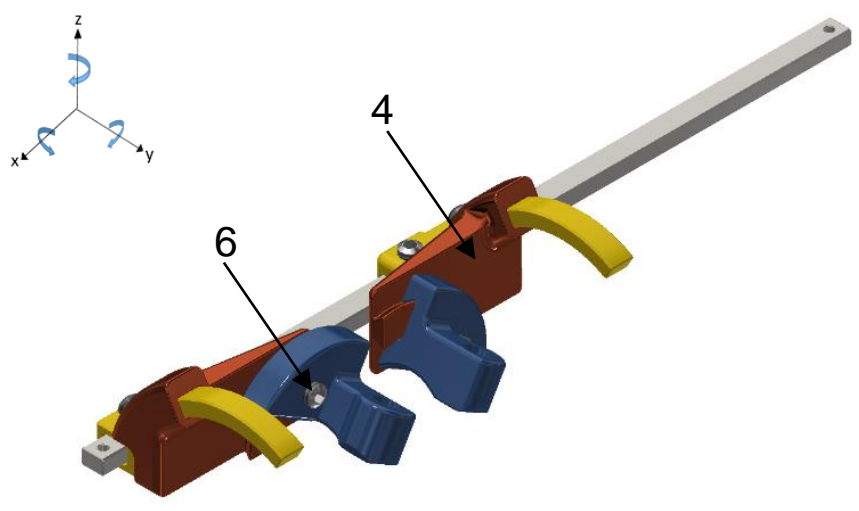

12. ábra Második konstrukciós változat

\subsection{Harmadik konstrukciós változat (13. ábra) [32]}

Ezen konstrukciós változat egyes elemei merőben mások, mint az előző esetekben. Az egyszerüsödés oka leginkább az volt, hogy a darabok gyárthatósága könnyebb legyen, de emellett figyelembe kellett venni a készülékekkel szembe támasztott követelményeket is. A készülék súlya itt is kicsinynek mondható, kb. $15 \mathrm{~g}$.

A szerkezeten látható, hogy a fúróvezető fejek (1) csak egy fix szöget képesek tartani, ezért más szögigény esetén ezeket a fejeket ki kell cserélni egy másik adott szögű fejre. Minden egyes szögértékhez külön fejet kell legyártani, ezáltal variálhatóvá válik a készülék és mindig az éppen szükséges fej beszerelhető. Az egyes darabok itt is hernyócsavarral (3) rögzíthetők az adott pozícióban. A 4-es számú darab tartja az egész szerkezetet.

Hátránya a készüléknek az, hogy a furatokkal ellátott fejek nem képesek elfordulni, viszont $x$, $y, z$ tengelyek irányában el tudnak mozdulni. Az elmozdulás mértéke látható, leolvasható és beállitható a készüléken. Erre szolgálnak a rovátkák és a kezdő pozíció jelzése, amelyek az 1-es és 2-es számú darabokon vannak jelölve.

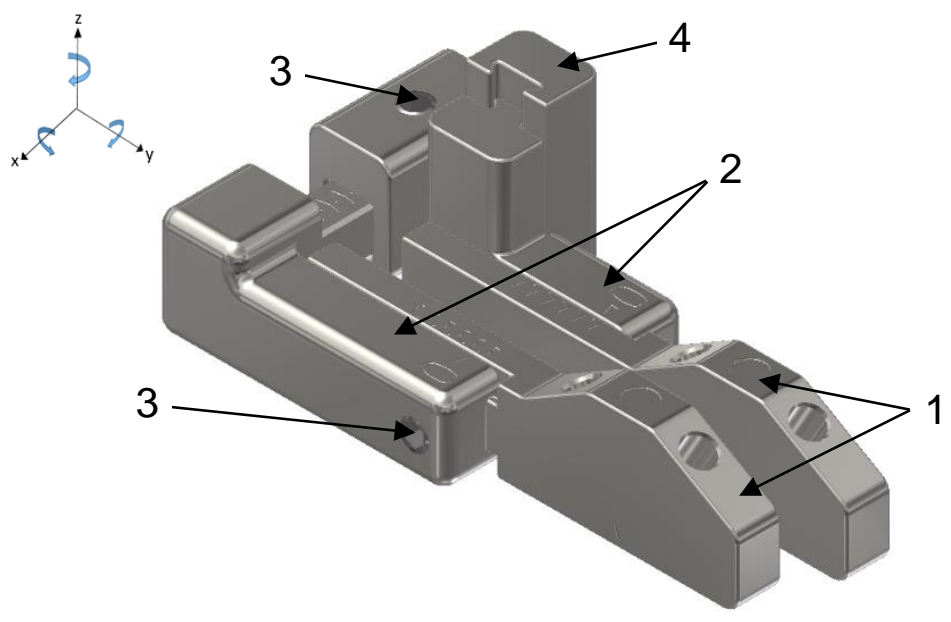

13. ábra Harmadik konstrukciós változat

\subsection{Negyedik konstrukciós változat (14. ábra) [33]}

Ebben a konstrukcióban az 1-es jelű darabok már elfordulásra is képesek y tengely körül a 2sel jelölt darabokon kialakított sínpálya mentén. Minden darab helyzetét itt is hernyócsavarral lehet rögzíteni (3). A 1-es jelü darabok cserélhető fejek, attól függően, hogy épp milyen szögben kell majd fúrni furatot a csontba. A fejeken lévő szám adja meg, hogy milyen szögben lehet fúrni. Három irányba mozgatható ( $x, y, z$ tengely mentén) és egy tengely $(y)$ körül elforgatható a készülék. Az 5ös jelü darabok tartják a 2-es jelű darabokat, illetve a hozzájuk csatlakozó cserélhető fejeket (1). A 
rúd (4) rövidebb, így a beteg szájába történő behelyezésekor a sérülés veszélye minimális, viszont a készülék kézben tartása nehézkes. A rúd végén lévő furatba damil van füzve az esetleges lenyelés elkerülése végett.

A szerkezet beállithatósága könnyünek mondható, maga a szerkezet súlya is minimális, alig $10 \mathrm{~g}$

Hátránya még a készüléknek hogy a rúd rövidsége miatt csak az elöl lévő fogak pótlásához lehet alkalmazni, a hátsó régiókban nem, épp a készülék kicsiny mérete, illetve a készülék kézben tartása miatt.

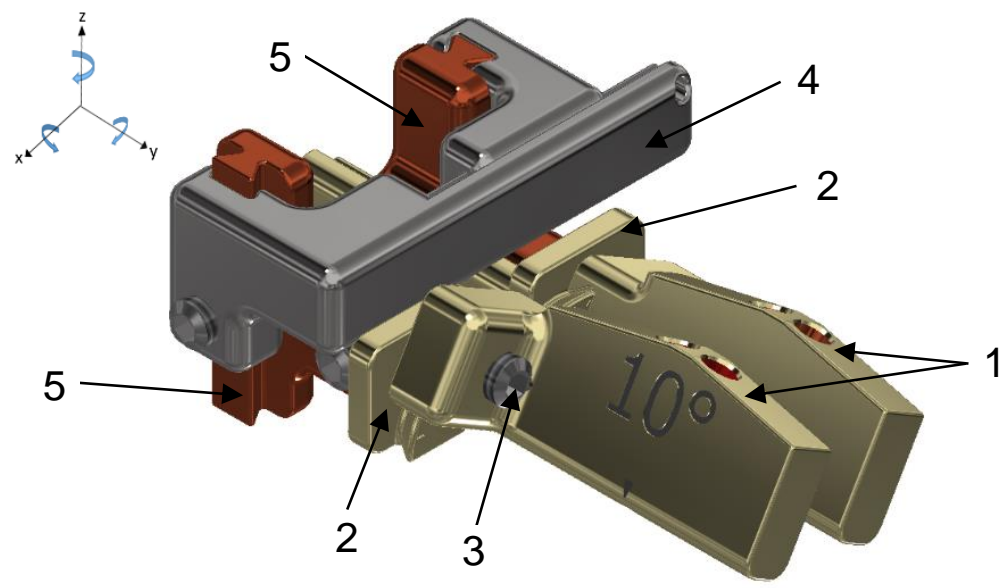

14. ábra Negyedik konstrukciós változat

\section{5. Ötödik, végleges konstrukciós változat (15. ábra) [34]}

Ez a készülék kialakítás már tudja mindazokat a funkciókat, amelyeket elvárunk tőle.

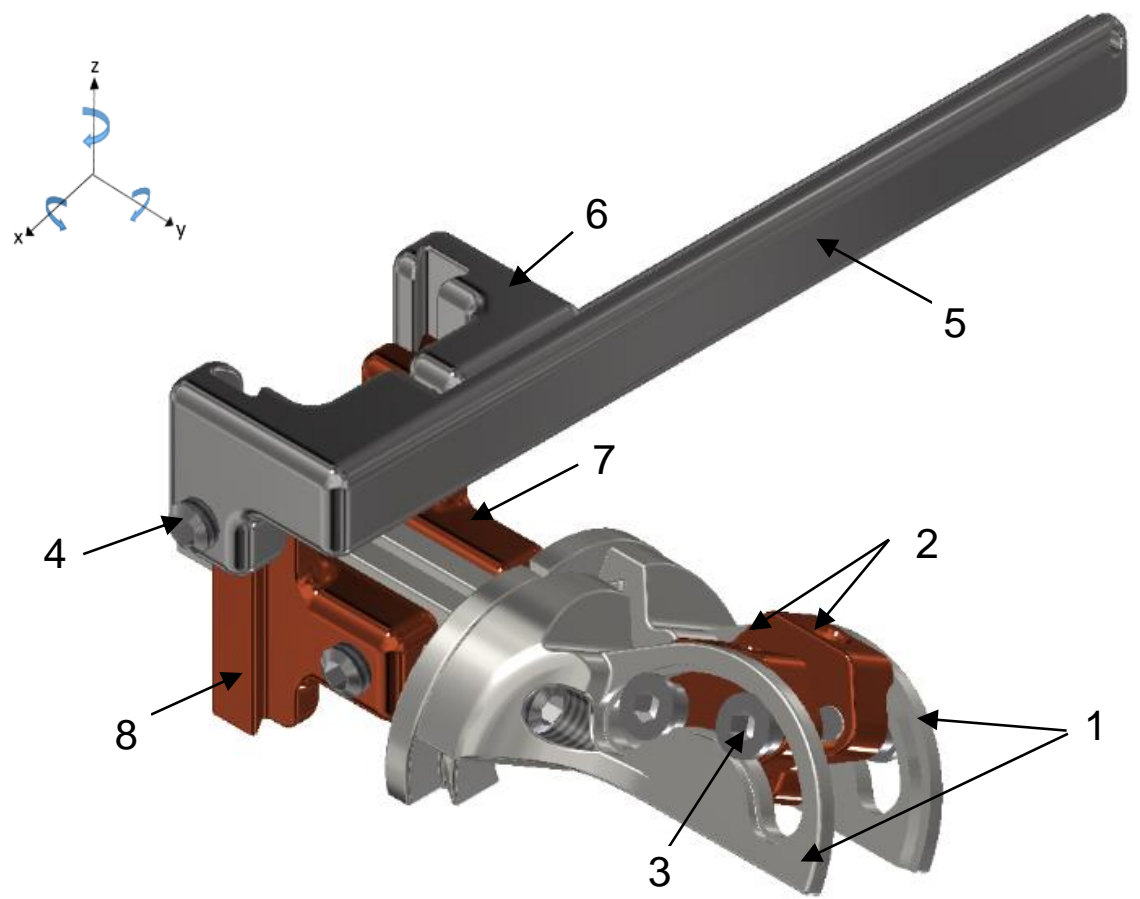

15. ábra Ötödik, végleges konstrukció

A készülékben már minden olyan irányban tudjuk mozgatni az egyes darabokat, amire szükség van. Emellett a fúró is kényelmesen elfér. A fúrás tengelyét nem csak elöre-hátra döntve, hanem oldalra is függetlenül állíthatjuk mind a két kar esetén (1), ráadásul rendkívül közel is tudunk 
egymáshoz fúrni, ami tüimplantátumok esetén nagyon fontos (két implantátum egy foghoz). Ezen darabok (2) állítása két csavarral (3) történik. A csavarok ezen daraboknál egyedi csavarok.

A többi elem hernyócsavarok (4) megszorításával rögzíthető egy adott pozícióban. Ezen pozíciók pontos helyzetét a 3D-s röntgenkép alapján lehet meghatározni. A rúd (5) hosszabb, ennél fogva irányítható, mivel ezt fogja a szájsebész. A rúdhoz csatlakozik a 6-os darab, amely segítségével a 7-es darab z, illetve x irányba történő elmozdulását lehet megvalósítani. A 8-as darab szintén a rúdhoz kapcsolódik. Mindkét darabot hernyócsavarral lehet rögzíteni a rúdhoz.

\section{Anyagválasztás, gyártás}

Minden egyes darab anyaga titán [35]. Könnyü és erős szerkezetre van szükségünk ahhoz, hogy a készüléken belül ne legyen törés, vagy deformálódás a használat során fellépő erők hatására. A titán esetében felmerülhet az ára, de ha a készülék többszöri felhasználhatóságát is figyelembe vesszük, akkor a kezdeti nagyobb költség kifizetődik. A célzó egyes darabjait azok bonyolult formája, gyárthatósága, illetve költséghatékonysága miatt 3D nyomtatással érdemes elkészíteni [36]. A 3D nyomtató gépek vagy valamilyen müanyag származékkal, vagy titánnal dolgoznak. [37]

A 3D nyomtatás pontossága befolyásolja azt az utómunkát, amit az egyes darabokon esetleg el kell még végezni. Egyszerübb darabok esetében a hagyományos megmunkáló központok is szóba jöhetnek, igaz a kis méret itt is okozhat problémát.

\section{Köszönetnyilvánítás}

Elsődlegesen szeretnék köszönetet mondani a cikk megszületéséhez szerzőtársamnak Dr. Urbán Gábor szájsebésznek, aki szakértelmével és ötleteivel hozzájárult ezen munka megszületéséhez. Az ő kitartó lelkesedése és ötleteinek sokasága nagyban segítette az elkészült konstrukció létrejöttét.

Emellett köszönetet mondanák Ivánovics Gergely kollégámnak a hasznos tanácsokért a cikk létrejöttéhez és annak tartalmához.

Köszönet illeti még Kovács Zsolt Ferenc csoportvezetöt, illetve Dr. Weltsch Zoltán tanszékvezetőt a támogatásukért!

\section{Irodalomjegyzék}

[1] http://www.naturaldental.hu/blog/straumann-implantatumok/

[2] egyedi CT felvétel

[3] saját szerkesztés

[4] https://i.ytimg.com/vi/K7c91E93rbQ/hqdefault.jpg

[5] http://www.drkeykha.com/images/article/\%D8\%A7\%D8\%A8\%D8\%A7\%D8\%AA\%D9\%85\%D9\%86\%D8\%AA.jpg

[6] https://www.sanitaria.hu/sg200l sebeszeti konyokdarab

[7] https://www.c-tech-implant.com/wp-content/uploads/2018/04/guide-surgery-surgical-protocol-c-tech-implant-05.jpg

[8] https://www.deardoctor.com/images/ddwc/features/how-technology-aids-dental-implant-therapy/dental-implantsurgical-guide.jpg

[9] https://cdeworld.com/media/10267

[10] https://www.clinicadentalcrookemarbella.com/wp-content/uploads/2019/02/guided-surgery.jpg

[11] https://kiralyfogaszat.hu/implantatum-beultetese-furosablonnal/

[12] https://www.clinicadentalcrookemarbella.com/wp-content/uploads/2019/02/guided-surgery.jpg

[13] https://www.c-tech-implant.com/wp-content/uploads/2018/04/guide-surgery-surgical-protocol-c-tech-implant-01.jpg

[14] https://www.image3dconversion.com/case-study/Surgical\%20Guides/6.jpg

[15] https://www.google.com/url?sa=i\&url=http\%3A\%2F\%2Fsemmelweis.hu\%2Fszajsebeszet\%2Ffiles\%2F2017\%2F02 $\% 2 F$ Spezielle-Implantatchirurgie.-M\%25C3\%25B6gliche-Zeitepunkte-derImplanation..pdf\&psig=AOvVaw1a3JExZuyho8gMzDc3zCnw\&ust=1612291101776000\&source=images\&cd=vfe\&v ed=2ahUKEwjV8bfEqsnuAhXYzSoKHfR1DA0Qjhx6BAgAEBI 14.dia

[16] https://d3i71xaburhd42.cloudfront.net/dad20d64f57ffd59db8ea5a2cd9aeeaca1e50f06/9-Figure13-1.png

[17] saját szerkesztés

[18] egyedi röntgenkép 
[19] https://hu.srimathumitha.com/zdorove/115755-krivaya-shpee-eto-chto-takoe.html

[20] https://mkik.hu/download/125/fogtechnikus-jegyzet

[21] Orentlicher G., Horowitz A., Abboud M.: Computer-guided implant surgery: indications and guidelines for use. Compend Contin Educ Dent . Nov-Dec 2012;33(10):720-32; quiz 733. PMID: 24964483

[22] Greenberg A. M.: Digital Technologies for Dental Implant Treatment Planning and Guided Surgery, Oral and Maxillofacial Surgery Clinics of North America Volume 27, Issue 2, May 2015, Pages 319-340 https://doi.org/10.1016/i.coms.2015.01.010

[23] egyedi 3D CT kép

[24] egyedi 3D CT kép

[25] egyedi CAD kép

[26] Gargallo-Albiol J., Shayan Barootchi, Marqués-Guasch J., Hom-Lay Wang: Fully Guided Versus Half-Guided and Freehand Implant Placement: Systematic Review and Meta-analysis, Int J Oral Maxillofac Implants. Nov/Dec 2020;35(6):1159-1169. https://doi.org/10.11607/jomi.7942

[27] egyedi kép

[28] https://scontent.fymy1-1.fna.fbcdn.net/v/t15.525610/p160x160/23382424 500770423628550 6493439391283806208 n.jpg? nc cat=107\&ccb=2\& nc sid=08861d \& nc ohc $=O n M j 7 B t D K 6 s A X-c x U q 2 \& \mathrm{nc} h \mathrm{ht}=$ scontent.fymy11.fna\&oh=a1849dd9f5e5ee0c834f3dafdb6a7070\&oe $=601 \mathrm{~F} 4949$

[29] M.-A. Fauroux, M. De Boutray, E. Malthie'ry, J.-H. Torres: New innovative method relating guided surgery to dental implant placement, https://doi.org/10.1016/i.jormas.2018.02.002

[30] saját készítés

[31] saját készítés

[32] saját készítés

[33] saját készítés

[34] saját készítés

[35] https://www.webbeteg.hu/cikkek/sebeszet/23590/implantatumok-fembol

[36] Sompop Bencharit DDS; MS; PhD, Staffen A. BSt, Yeung M. BSt, Whitley III D. DDS§, M. Laskin D. DDS MS\|, R. Deeb G. DDS MD.: In Vivo Tooth-Supported Implant Surgical Guides Fabricated With Desktop Stereolithographic Printers: Fully Guided Surgery Is More Accurate Than Partially Guided Surgery, Journal of Oral and Maxillofacial Surgery Volume 76, Issue 7, July 2018, Pages 1431-1439, https://doi.org/10.1016/j.joms.2018.02.010

[37] Pieralli S., Spies B. C., Hromadnik V., Nicic R., Beuer F., Wesemann C.: How Accurate Is Oral Implant Installation Using Surgical Guides Printed from a Degradable and Steam-Sterilized Biopolymer?, J. Clin. Med. 2020, 9(8), 2322; https://doi.org/10.3390/jcm9082322 